\title{
An Improved Evaluation of Network Platform and Harmonious Teaching Method in Women's Aerobics Education: an Empirical Research
}

\author{
Li Zhenliang ${ }^{1}$, Wan Ping ${ }^{2}$, Zhou Hang ${ }^{2}$ and Yuan Xiaozhi ${ }^{1, *}$ \\ ${ }^{1}$ P.E. Department, Jinggangshan University, Ji'an Jiangxi, China \\ ${ }^{2}$ P.E. Department, Shanghai Finance University, Shanghai, China \\ *jgsdxyxz@163.com
}

\begin{abstract}
After 1990s, the rapid development of information technology bring multimedia computer into the classroom, multimedia technology has gradually become a teaching method of physical education. In this paper, we study the harmonious teaching method in women's aerobics education by using contrast experiment. Through the testing and evaluation of 57 female college students, the result shows that harmonious teaching method can greatly improve the technical movements of the body, improve the quality of sports and psychological quality. After the experiment, students have a significant improve in technical action aerobics exercise, motion effects, action convergence, combinations action, action novelty, accuracy and movement dynamics action have significant increase. On this basis, we put forward relevant suggestions.
\end{abstract}

Keywords: Multimedia technology, Harmonious teaching, Aerobics, College education, Contrast experiment

\section{Introduction}

Multimedia teaching has a long history. The teachers' teaching is realized through sound, pictures and text. With the development of the times, science and production technology continues to improve, starting at the beginning of the eighties of the 20th century, teachers multimedia combination teaching, the use of a variety of electronic media, such as slides, video, video of comprehensive teaching, enter into the information society[1]. Multimedia computer into the classroom, multimedia teaching has gradually become the sports teaching method. Traditional aerobics teaching method is single, to the teacher in class to explain technology, simple demonstration to organize teaching. This kind of teaching form often can produce a teacher to complete the teaching task from the form; it is difficult to make the students in the limited time to grasp the sports of the various technical action methods. Has affected the enthusiasm of students learning, students cannot participate in the learning activities, physical and mental development, is not conducive to the cultivation of lifelong physical training[2]. Multimedia assisted high school aerobics teaching, a variety of sensory stimulation of the cognitive activities to determine the effect of cognitive activities of students, improve the learning efficiency of student's skills. In the teaching of multimedia, the combination of graph and text, the combination of dynamic and static, the interest of students' autonomous learning is stimulated, and the students are guided by passive acceptance of knowledge. In the reform of physical education, the application of multimedia in the classroom teaching can provide students with interest in active learning. It is beneficial to cultivate students' ability to explore learning and promote students' ability to study and standardize, improve students' ability to find and solve the wrong action.

${ }^{*}$ Corresponding Author 
In the report of the new education idea and the full implementation of quality education, Lu Yongxiang, vice chairman of the Standing Committee of the National People's Congress, pointed out that China's examination oriented education from primary school to university education at all stages have some problems, the neglect of students' knowledge and learning ability, resulting in some lack of learning interest, learning initiative spirit and innovation consciousness [3]. At present, the development of Aerobics in Colleges and universities is very fast, but the research on the aerobics teaching method is still in the primary stage. Traditional aerobics teaching makes students study passively, and it is easy to cause the students to get tired of students [4]. It is the key to play the students' subjectivity and enthusiasm. The harmonious teaching method is based on the teaching practice and the promotion of the "comprehensive quality" education, the inheritance and innovation of traditional education is the ultimate goal and the highest state of the unity of the truth, goodness and beauty. The female students in 57 of height, weight, heart rate, vital capacity, 50 meters, long jump, 800 meters, sitting body flexion, sit ups, mental health, action of a set of specified and designed operation action technology index measurement, test and evaluation. The purpose is to in further validation of Aerobics theory and technology to improve the effect of; harmonious teaching method on students' physical and mental health effects of the effect; to further aerobics teaching reform to provide a reference basis.

\section{Literature Review}

\subsection{Multimedia Technology}

Multimedia which consists of two parts, media and multi, is general be understand as a variety of media. Or directly to the generic term for a person the sense organ of text, graphics, images, animation, sound and video media, namely the manifestation of various information carriers and transfer. While the aerobics of this sport, cannot be separated from the action skills and music, the movement skills of the continuous changes in the space and time, improve the people's exercise of the comprehensive, detail, but also to improve the sport's view. From different perspectives, the media will have different descriptions[5]. From the literal understanding, multimedia is a variety of media, but it is often closely related to the computer, so the multimedia is mainly refers to the diversification of computer processing information. As the process of processing information, processes or activities can be regarded as the media, so that computers, televisions, etc. can be regarded as a multimedia tool[6]. Therefore, from the broad sense, the multimedia is a domain, is refers to the information processing related all the technology and the method, including the broadcast communication, the home appliance, the printing press and so on. In the narrow sense, the multimedia is the collection of the text, graphics, images, sound, animation and video information which is transmitted by computer. So far, there is no accurate definition of multimedia. In short, we live in the "multimedia", often related to information media, including information itself, information access, information storage, information processing, information output, and a series of information related to all technologies and methods. The multimedia in the teaching of aerobics is the embodiment of the multimedia, including the production, the demonstration of the multimedia courseware, and the use of the multimedia tools and tools. The use of multimedia in the teaching of aerobics is the embodiment of modern educational technology, and is the important symbol of the difference between the traditional teaching mode and the traditional teaching mode.

Multimedia teaching is in the teaching process, according to the teaching objectives and characteristics of the object, through teaching design, reasonable 
choice and the use of modern teaching media, and with the traditional teaching method of organic combination, to participate in the teaching process, with a variety of media information to the students, forming a reasonable teaching process structure, to achieve the optimization of teaching effect[7]. There are two main ways in the teaching of Aerobics Teaching: one is to adopt the form of multimedia courseware in the teaching of theory; one is to use the combination of multimedia and equipment in practice.

\subsection{Physical Education Teaching}

The main purpose of the competition is to get good results, and the action is arranged in the specific rules and regulations. The strength and flexibility of the body must be displayed in the complete set of movements, and not repeat. Action difficulty, technical skills and artistic performance requirements, generally more suitable for heart and lung function, good physical quality of young people. Through the survey of 57 college sports multimedia technology backbone teachers in 27 provinces and cities nationwide, $31.25 \%$ colleges and universities have been used to carry out the teaching of multimedia assisted teaching. $68.75 \%$ of the University's physical education courses have been used to carry out the teaching [8]. The $15.63 \%$ colleges and universities have already begun to pay attention to the teaching of physical education. Sports Multimedia CAI is a very good auxiliary tool in physical education teaching [9]. Because it has the characteristics of strong interactivity, rich content, and the accuracy of the display technology, it is the same as the students. However, because of the limitation of traditional sports teaching idea and the information ability of the teachers themselves, it is not reasonable and effective use of sports media CAI in physical education teaching.

Richard E. Meyer, the United States well-known educational psychologist and cognitive psychology expert, has been the leading figure in the Multimedia, to explore how people are learning and how to help people learning is a special purpose of Meyer, Meyer is defined as the presentation of text, such as pictures, pictures, animation or video [10]. Meyer will be cognitive theory, teaching and multimedia integration, build a multimedia learning theory of cognitive model. From the above, it can be seen that multimedia has been popularized in Colleges and universities, and the application effect is consistent with students. However, due to the limitation of teacher's ideas and multimedia operating ability, the application of multimedia in teaching of physical education is very low. So the application of multimedia in aerobics teaching is very good.

\section{Research Object and Main Method}

\subsection{Time and Objects}

Study time from February 2015 to June 2015, a total of 16 weeks. Research object: 57 female students in the public option class of 2013 class two large scale of Jinggangshan University (experimental group 29, control group 28) were studied.

\subsection{Research Method}

The main research method including:

1) Literature method: according to the research purposes, contents and requirements, through the Shanghai Institute of Physical Education library, Jinggangshan university library, China Academic Journal Network, sports academic journal, Jinggangshan University Sports Institute (physical education, teaching practice, psychological and other aspects), access to and 
collate the relevant harmonious teaching method of the results and research frontier. To further explore the results of previous studies, reading related professional books, to provide a theoretical basis for the study.

2) Interviews: developing access content outline, has a wealth of experience, more research of Aerobics specialist visits and telephone interviews, access to their precious data to, in harmonious teaching method has outstanding research progress on issues related to interview and record and finishing, forming certain suggestions and theoretical basis.

3) Questionnaire: first of all, according to the existing data and experience and questionnaire design requirements, determine the content of the questionnaire, the design of the experiment before the aerobics students' questionnaire and the students' questionnaire survey, and repeatedly revise and improve, to ensure the validity and objectivity of the contents of the questionnaire. Secondly, the distribution and recovery of the questionnaire: the questionnaire of the students' basic information, psychological quality, physical fitness and aerobics skills were 60,57, 100\%, 95\% and 60. Again, it is a valid test: the content of the questionnaire was given to 10 experts, and the validity of the questionnaire was tested. The overall validity is very suitable for 6 people, 3 people, the basic right of 1 people, the other no, visible, through the results of the experts, the questionnaire is effective. Finally the reliability test, reliability test using the test-retest method, namely in the Aerobics Teaching Effectiveness Questionnaire recovery within 14 days of questionnaire were again measured, $0.88, \mathrm{p}=0.000<0.01$, visible questionnaire reliability have greater reliability and authenticity.

4) Test method: 57 female undergraduates in $(29$ girls in the experimental group and the control group of girls 28) of height, weight, heart rate, vital capacity, 50 meters, long jump, 800 meters, sitting body flexion, index of sit ups, and a set of specified action and self testing and evaluation of technical movements.

5) Comparative analysis: before and after the experiment, the two groups were compared.

6) Statistical method: using SPSS18.0 software to survey data results for statistical processing $(\mathrm{P}>0.05$ indicates no significant difference between the two groups; $0.01<\mathrm{P}<0.05$ indicates significant difference between the two groups; $\mathrm{P}<0.01$ indicates a very significant difference between the two groups.

7) Logical analysis: by using the method of comparison, deduction, induction, analysis, reasoning and so on.

\subsection{Experimental Method}

In the experimental group, the traditional sports teaching method and the harmonious teaching method were applied to women's aerobic teaching. The experimental group and the control group were compared with the experimental group and the control group. Experimental study using single blind experiment, do not let students know their own experimental group or control group, to avoid abnormal mentality, psychology and behavior to influence the experiment. In the teaching process, the teacher mainly through the explanation, demonstration teaching, pay attention to each group of action details to explain the process of the aerobics learning. 
The main content of experiment: physical form test, physical function test, physical fitness test, the whole set of technical evaluation, self compiled action technique, psychological quality index. Experiment: the experimental group uses the harmonious teaching method and the traditional physical education teaching method, the control group uses the traditional sports teaching method factor. The control of the experiment process of the harmonious teaching method: first is the experimental object control in Jinggangshan university public sports big two aerobics option class 57 people. Secondly, the experimental conditions of the control range, the experimental group of teaching syllabus, teaching progress, teaching plans, teaching facilities, teaching equipment, teaching time, teaching content, teaching content, teaching, sports, teaching and exercise load, and the control group. Once again, the control of the participants in the experimental group and the control group of students in the experimental group were held by a group of aerobics. Finally, the control of experimental evaluation: aerobics teaching content assessment and sports quality test, the experimental group and control group of female students in the group and the order to carry out the evaluation, test evaluation by 3 years of experience in the aerobics teacher, to ensure the reliability of the results of the experiment. Harmonious teaching method experimental design: Aerobics teachers into the new curriculum; clear goals - self-study guidance; students to perceive the whole - check the coaching; students explore the rule standard practice; students to broaden and improve - from theory to practice to return to theory that iteratively improves. Harmonious teaching method experimental steps: before and after the experiment, the data of the two groups of boys body of basic index test; before and after the experiment on two groups of girls aerobics exercise (50 meters, long jump, 800 meters, sitting body flexion, index of sit ups) quality testing; inspection before and after the two groups of girls aerobics motor skills (a set of specified action, self operation) technology to carry on the evaluation; before and after the experiment on two groups of girls psychological health standard index were measured.

\section{Empirical Analysis}

\subsection{Comparison between Experimental Group and Control Group}

4.1.1. Comparative Analysis of Body Shape and Function: Before the experiment the experimental group and the control group were measured body shape and function, through SPSS software processing, the results in Table 1 show: in height, the experimental group $(159.17 \pm 5.37)$, in the control group $(158.96 \pm 5.32)$, and the difference $=0.21 \mathrm{~cm}, \mathrm{~F}=0.022, \mathrm{P}=0.884>0.05$; in weight, the experimental group $(54.75 \pm 3.67)$, in the control group $(54.46 \pm 4.35)$, and the difference $=0.29 \mathrm{~kg}, \mathrm{~F}=$ $0.076, \mathrm{P}=0.783>0.05$; heart rate in the experimental group $(73.96 \pm 4.70)$, in the control group $(74.21 \pm 4.58)$, and the difference $=-0.25$ times, $\mathrm{F}=0.041, \mathrm{P}=0.841>0.05$; in vital capacity, the experimental group $(2239.7 \pm 544.67)$, control group $(2280.4 \pm 613.48)$, and the difference $=-40.7 \mathrm{ml}, \mathrm{F}=0.070, \mathrm{P}=0.792>0.05 . \mathrm{F}$ value is close to $0, \mathrm{P}>0.05$, no statistically significant differences, indicating that before the experiment the experimental group and the control group body shape and function basically the same, to provide protection for the findings. 
Table 1. Comparison Analysis of Height, Weight and Heart Rate $(n=57)$

\begin{tabular}{|c|c|c|c|c|c|}
\hline Index & $\begin{array}{c}\text { Experimental } \\
\text { group }(\mathrm{X} \pm \mathrm{S})\end{array}$ & $\begin{array}{c}\text { Control } \\
\text { group }(\mathrm{X} \pm \mathrm{S})\end{array}$ & difference & F value & P value \\
\hline Height $(\mathrm{CM})$ & $159.17 \pm 5.37$ & $158.96 \pm 5.32$ & 0.21 & 0.022 & 0.884 \\
\hline Weight $(\mathrm{kg})$ & $54.75 \pm 3.67$ & $54.46 \pm 4.35$ & 0.29 & 0.076 & 0.783 \\
\hline Heart rate (CI) & $73.96 \pm 4.70$ & $74.21 \pm 4.58$ & -0.25 & 0.041 & 0.841 \\
\hline $\begin{array}{c}\text { Vital capacity } \\
\text { (ML) }\end{array}$ & $2239.7 \pm 544.67$ & $2280.4 \pm 613.48$ & -40.7 & 0.070 & 0.792 \\
\hline
\end{tabular}

4.1.2. Comparative Analysis on the Quality of Aerobics: Before the experiment the experimental group and the control group Aerobics quality testing, through SPSS software processing, the results in Table 2 show: in the 50 meters, the experimental group $(9.31 \pm 0.62)$, in the control group $(9.24 \pm 0.55)$, and the difference $=0.07 \mathrm{~s}, \mathrm{~F}=0.187, \mathrm{P}$ $=0.667>0.05$; in the long jump, the experimental group $(166.93 \pm 12.24)$, in the control group $(168.86 \pm 11.97)$, and the difference $=-0.93 \mathrm{~cm}, \mathrm{~F}=0.360, \mathrm{P}=0.551>0.05 ;$ In the 800 meters, the experimental group $(254.41 \pm 14.56)$, in the control group (252.25 \pm 17.54 ), and the difference $=2.16 \mathrm{~s}, \mathrm{~F}=0.257, \mathrm{P}=0.614>0.05$; in the Sit and Reach, the experimental group $(10.76 \pm 4.23)$ and control group $(11.64 \pm 4.69)$, and the difference $=$ $-0.86 \mathrm{~cm}, \mathrm{~F}=0.559, \mathrm{P}=0.458>0.05$; sit-ups in the experimental group $(27.83 \pm 3.02)$, in the control group $(28.36 \pm 2.69)$, and the difference $=-0.53$ points, $\mathrm{F}=0.485, \mathrm{P}=0.489>$ 0.05 . F value is close to $0, \mathrm{P}>0.05$, no statistically significant differences, indicating that before the experiment the experimental group and the control group Aerobics consistent quality, to provide protection for the findings.

Table 2. Comparison Analysis of 50 Meters, Long Jump and 800 Meters ( $n=$ 57)

\begin{tabular}{|c|c|c|c|c|c|}
\hline Index & $\begin{array}{c}\text { Experimental } \\
\text { group }(\mathrm{X} \pm \mathrm{S})\end{array}$ & $\begin{array}{c}\text { Control } \\
\text { group }(\mathrm{X} \pm \mathrm{S})\end{array}$ & difference & F value & P value \\
\hline 50 meters (s) & $9.31 \pm 0.62$ & $9.24 \pm 0.55$ & 0.07 & 0.187 & 0.667 \\
\hline Long jump & $166.93 \pm 12.24$ & $168.86 \pm 11.97$ & -0.93 & 0.360 & 0.551 \\
\hline 800 meters (s) & $254.41 \pm 14.56$ & $252.25 \pm 17.54$ & 2.16 & 0.257 & 0.614 \\
\hline Sit and reach & $10.76 \pm 4.23$ & $11.64 \pm 4.69$ & -0.86 & 0.559 & 0.458 \\
\hline Sit ups (a) & $27.83 \pm 3.02$ & $28.36 \pm 2.69$ & -0.53 & 0.485 & 0.489 \\
\hline
\end{tabular}

4.1.3. Comparative Analysis of Technical Movements of Aerobic Gymnastics: Before the experiment the experimental group and the control group aerobics for evaluation of technical movements, through SPSS software processing, the results in Table 3 show: the action expressive force, the experimental group $(8.10 \pm 0.86)$, in the control group $(8.12 \pm$ 0.74 ), and the difference $=-0.02$ points, $\mathrm{F}=0.010, \mathrm{P}=0.920>0.05$; accuracy in operation, the experimental group $(7.67 \pm 0.94)$, in the control group $(7.84 \pm 0.81)$, and the difference $=-0.17$ points, $\mathrm{F}=0.517, \mathrm{P}=0.475>0.05$; in the range of motion in the experimental group $(7.07 \pm 1.09)$, in the control group $(7.23 \pm 1.01)$, and the difference $=$ -0.15 points, $\mathrm{F}=0.339, \mathrm{P}=0.563>0.05$; in movement dynamics (in the experiment group $(6.74 \pm 1.08)$, in the control group $(7.07 \pm 0.99)$, and the difference $=-0.33$ points, $\mathrm{F}=$ $1.443, \mathrm{P}=0.235>0.05$.F value close to $0, \mathrm{P}>0.05$, no statistically significant differences explain the experimental group before the experiment is consistent with the control group aerobics technical operation level, to provide protection for the findings. 
Table 3. Comparison Analysis of Technical Assessment of Action $(n=57)$

\begin{tabular}{|c|c|c|c|c|c|c|}
\hline Index & score & $\begin{array}{c}\text { Experimental } \\
\text { group }(\mathrm{X} \pm \mathrm{S})\end{array}$ & $\begin{array}{c}\text { Control } \\
\text { group }(\mathrm{X} \pm \mathrm{S}\end{array}$ & difference & $\begin{array}{c}\mathrm{F} \\
\text { value }\end{array}$ & $\begin{array}{c}\mathrm{P} \\
\text { value }\end{array}$ \\
\hline Performance & 10 & $8.10 \pm 0.86$ & $8.12 \pm 0.74$ & -0.02 & 0.010 & 0.920 \\
\hline Accuracy & 10 & $7.67 \pm 0.94$ & $7.84 \pm 0.81$ & -0.17 & 0.517 & 0.475 \\
\hline Action range & 10 & $7.07 \pm 1.09$ & $7.23 \pm 1.01$ & -0.15 & 0.339 & 0.563 \\
\hline $\begin{array}{c}\text { Action } \\
\text { dynamics }\end{array}$ & 10 & $6.74 \pm 1.08$ & $7.07 \pm 0.99$ & -0.33 & 1.443 & 0.235 \\
\hline
\end{tabular}

4.1.4. Comparative Analysis of Mental Health: Before the experiment the experimental group and the control group to measure mental health, through SPSS software processing, the results in Table 4 show: in normal intelligence, the experimental group $(7.17 \pm 1.36)$, in the control group $(7.42 \pm 1.31)$, and the difference $=-0.25$ points, $\mathrm{F}=0.519, \mathrm{P}=$ $0.474>0.05$; at the appropriate emotional control, the experimental group $(5.93 \pm 2.10)$, in the control group $(6.21 \pm 2.06)$, and the difference $=-0.28$ points, $\mathrm{F}=0.263, \mathrm{P}=0.610$ > 0.05 ; in on their own can make a proper evaluation of the experimental group $(6.41 \pm$ $2.09)$, in the control group $(6.64 \pm 1.88)$, and the difference $=-0.23$ points, $\mathrm{F}=0.187, \mathrm{P}=$ $0.667>0.05$; in maintaining good relationships, the experimental group ( $5.86 \pm 1.99)$, in the control group $(6.00 \pm 1.96)$, and the difference $=-0.14$ points, $\mathrm{F}=0.069, \mathrm{P}=0.794>$ 0.05 . F value is close to $0, \mathrm{P}>0.05$, no statistically significant differences, indicating that before the experiment the experimental group and the control group mental health basically the same, to provide protection for the findings.

Table 4. Comparison Analysis of Mental Health Indicators $(n=57)$

\begin{tabular}{|c|c|c|c|c|c|c|}
\hline Index & score & $\begin{array}{c}\text { Experimenta } \\
1 \text { group }(\mathrm{X} \pm \\
\mathrm{S})\end{array}$ & $\begin{array}{c}\text { Control } \\
\text { group }(\mathrm{X} \pm \\
\mathrm{S})\end{array}$ & $\begin{array}{c}\text { differenc } \\
\mathrm{e}\end{array}$ & $\begin{array}{c}\mathrm{F} \\
\text { value }\end{array}$ & $\begin{array}{c}\mathrm{P} \\
\text { value }\end{array}$ \\
\hline Normal intelligence & 10 & $7.17 \pm 1.36$ & $7.42 \pm 1.31$ & -0.25 & 0.519 & 0.474 \\
\hline Emotional control & 10 & $5.93 \pm 2.10$ & $6.21 \pm 2.06$ & -0.28 & 0.263 & 0.610 \\
\hline $\begin{array}{c}\text { Appropriate } \\
\text { evaluation }\end{array}$ & 10 & $6.41 \pm 2.09$ & $6.64 \pm 1.88$ & -0.23 & 0.187 & 0.667 \\
\hline $\begin{array}{c}\text { Good interpersonal } \\
\text { skills }\end{array}$ & 10 & $5.86 \pm 1.99$ & $6.00 \pm 1.96$ & -0.14 & 0.069 & 0.794 \\
\hline
\end{tabular}

\subsection{Comparison after the Experiment}

4.2.1. Comparative Analysis of Body Shape and Function after the Experiment: After the experiment the experimental group and the control group were measured body shape and function, through SPSS software processing, the results in Table 5 show: in height, the experimental group $(159.93 \pm 4.88)$, in the control group $(159.14 \pm 5.58)$, and the difference $=0.79 \mathrm{~cm}, \mathrm{~F}=0.323, \mathrm{P}=0.572>0.05$; in weight, the experimental group $(52.03 \pm 4.38)$, in the control group $(54.39 \pm 4.36)$, and the difference $=-2.37 \mathrm{~kg}, \mathrm{~F}=$ 4.136, $\mathrm{P}=0.047<0.05$; in Heart rate, the experimental group $(71.17 \pm 5.91)$, in the control group $(74.03 \pm 4.29)$, and the difference $=-2.86$ times, $\mathrm{F}=4.349, \mathrm{P}=0.042<0.05$; in vital capacity, the experimental group $(2401.3 \pm 548.60)$, control group (2255.4 \pm 574.99), and the difference $=145.9 \mathrm{ml}, \mathrm{F}=1.085, \mathrm{P}=0.302>0.05$. Second row in descending order were: heart rate, weight, vital capacity, height. This is because aerobics teaching, have more time to devote to aerobic exercise, can reduce heart rate, consumption of excess fat and weight loss, while breathing speed up, to have more lung capacity increase, but college students passed the development stage, factors affecting 
height and more, so the height change is not great and lead. Visible, heart rate and body weight were significantly increased lung capacity have greatly improved improved height unchanged.

Table 5. Comparison Analysis of Height, Weight, Heart Rate, Lung Capacity after Experiment $(n=57)$

\begin{tabular}{|c|c|c|c|c|c|}
\hline Index & $\begin{array}{c}\text { Experimental } \\
\text { group }(\mathrm{X} \pm \mathrm{S})\end{array}$ & $\begin{array}{c}\text { Control group }(\mathrm{X} \\
\pm \mathrm{S})\end{array}$ & difference & $\begin{array}{c}\mathrm{F} \\
\text { value }\end{array}$ & P value \\
\hline Height $(\mathrm{CM})$ & $159.93 \pm 4.88$ & $159.14 \pm 5.58$ & 0.79 & 0.323 & 0.572 \\
\hline Weight $(\mathrm{kg})$ & $52.03 \pm 4.38$ & $54.39 \pm 4.36$ & -2.37 & 4.136 & 0.047 \\
\hline Heart rate $(\mathrm{CI})$ & $71.17 \pm 5.91$ & $74.03 \pm 4.29$ & -2.86 & 4.349 & 0.042 \\
\hline $\begin{array}{c}\text { Vital capacity } \\
(\mathrm{ML})\end{array}$ & $2401.3 \pm 548.60$ & $2255.4 \pm 574.99$ & 145.9 & 1.085 & 0.302 \\
\hline
\end{tabular}

4.2.2. Quality of Aerobics after the Experiment: Experimental group and control group Aerobics quality test after test, through SPSS software processing, the results in Table 6 show: 50 meters, the experimental group $(8.93 \pm 0.46)$, in the control group $(9.23$ \pm 0.57 ), and the difference $=-0.30 \mathrm{~s}, \mathrm{~F}=4.433, \mathrm{P}=0.040<0.05$; in the long jump, the experimental group $(176.03 \pm 12.25)$, in the control group $(169.57 \pm 11.71)$, and the difference $=6.46 \mathrm{~cm}, \mathrm{~F}=4.138, \mathrm{P}=0.047<0.05$; In the 800 meters, the experimental group $(242.31 \pm 10.15)$, in the control group $(250.75 \pm 17.78)$, and the difference $=-8.44 \mathrm{~s}$, $\mathrm{F}=4.883, \mathrm{P}=0.031<0.05 ;$ in the Sit and Reach, the experimental group $(14.79 \pm 3.67)$ and control group $(11.71 \pm 4.41)$, and the difference $=3.08 \mathrm{~cm}, \mathrm{~F}=8.211, \mathrm{P}=0.006$ $<0.01$; in sit-ups, the experimental group $(30.72 \pm 5.35)$, in the control group $(28.11 \pm$ 2.88 ), and the difference $=2.61, \mathrm{~F}=5.217, \mathrm{P}=0.026<0.05$. Order of ranking in descending order: sit and reach, sit-ups, 800 meters, 50 meters, long jump. This is because teaching aerobics movement, the waist is the hub of important parts of the body, its flexibility and strength, force and endurance run in the movement to improve and lead to continuous improvement. Visible, Sit and Reach has a very significant increase, sit-ups, 800 meters, 50 meters, long jump significantly improved.

Table 6. 50 Meters, Long Jump and 800 Meters after the Experiment $(n=57)$

\begin{tabular}{|c|c|c|c|c|c|}
\hline Index & $\begin{array}{c}\text { Experimental } \\
\text { group }(\mathrm{X} \pm \mathrm{S})\end{array}$ & $\begin{array}{c}\text { Control group }(\mathrm{X} \\
\pm \mathrm{S})\end{array}$ & difference & $\begin{array}{c}\mathrm{F} \\
\text { value }\end{array}$ & $\begin{array}{c}\mathrm{P} \\
\text { value }\end{array}$ \\
\hline 50 meters (s) & $8.93 \pm 0.46$ & $9.23 \pm 0.57$ & -0.30 & 4.433 & 0.040 \\
\hline Long jump (cm) & $176.03 \pm 12.25$ & $169.57 \pm 11.71$ & 6.46 & 4.138 & 0.047 \\
\hline 800 meters (s) & $242.31 \pm 10.15$ & $250.75 \pm 17.78$ & -8.44 & 4.883 & 0.031 \\
\hline Sit and reach & $14.79 \pm 3.67$ & $11.71 \pm 4.41$ & 3.08 & 8.211 & 0.006 \\
\hline Sit ups (a) & $30.72 \pm 5.35$ & $28.11 \pm 2.88$ & 2.61 & 5.217 & 0.026 \\
\hline
\end{tabular}

4.2.3. Technical Movements of Aerobic Gymnastics after the Experiment: After the experiment the experimental group and the control group aerobics predetermined operation of the entire evaluation, through SPSS software processing, Table 7. The results show that: in the action expression, the experimental group $(8.55 \pm 0.98)$, in the control group $(8.05 \pm 0.88)$, and the difference $=0.50, \mathrm{~F}=4.486, \mathrm{P}=0.039<0.05$; accuracy in operation, the experimental group $(8.53 \pm 0.70)$, in the control group $(7.91 \pm 0.72)$, and the difference $=0.62, \mathrm{~F}=10.891, \mathrm{P}=0.002<0.01$; in the range of motion in the experimental group $(7.84 \pm 0.97)$, in the control group $(7.28 \pm 0.92)$, and the difference $=$ $0.56, \mathrm{~F}=4.972, \mathrm{P}=0.030<0.05$; in movement dynamics, the experimental group $(7.93 \pm$ $1.12)$, in the control group $(7.14 \pm 0.86)$, and the difference $=0.79, \mathrm{~F}=8.803, \mathrm{P}=0.004$ 
$<0.01$. Order of ranking in descending order: Action accuracy, movement dynamics, range of motion, action expression. This is because aerobics entire predetermined operation, accurate operation is an operation of the entire operation of the fundamental effect; it needs to force the action, curvature and expressive force to achieve a result. Visible, accuracy and movement dynamics action very significant increase range of motion and action expressive force has significantly improved.

Table 7. Comparison Analysis of Technical Assessment of Action $(n=57)$

\begin{tabular}{|c|c|c|c|c|c|c|}
\hline Index & score & $\begin{array}{c}\text { Experimental } \\
\text { group }(\mathrm{X} \pm \mathrm{S})\end{array}$ & $\begin{array}{c}\text { Control } \\
\text { group }(\mathrm{X} \pm \mathrm{S}\end{array}$ & difference & $\begin{array}{c}\mathrm{F} \\
\text { value }\end{array}$ & $\begin{array}{c}\mathrm{P} \\
\text { value }\end{array}$ \\
\hline Performance & 10 & $8.55 \pm 0.98$ & $8.05 \pm 0.88$ & 0.50 & 4.486 & 0.039 \\
\hline Accuracy & 10 & $8.53 \pm 0.70$ & $7.91 \pm 0.72$ & 0.62 & 10.891 & 0.002 \\
\hline Action range & 10 & $7.84 \pm 0.97$ & $7.28 \pm 0.92$ & 0.56 & 4.972 & 0.030 \\
\hline $\begin{array}{c}\text { Action } \\
\text { dynamics }\end{array}$ & 10 & $7.93 \pm 1.12$ & $7.14 \pm 0.86$ & 0.79 & 8.803 & 0.004 \\
\hline
\end{tabular}

After the experiment the experimental group and the control group aerobics exercise self motion technology assessment, through SPSS software processing, Table 8 results show: In action novel, the experimental group $(8.64 \pm 0.94)$, in the control group $(7.83 \pm$ 1.09), and points difference $=0.81, \mathrm{~F}=8.695, \mathrm{P}=0.005<0.01$; convergence in action, the experimental group $(8.62 \pm 0.64)$, in the control group $(7.55 \pm 1.06)$, and the difference $=$ $1.07 \mathrm{~min}, \mathrm{~F}=20.995, \mathrm{P}=0.000<0.01$; the number of combinations in the action, the experimental group $(8.07 \pm 0.90)$, in the control group $(7.14 \pm 0.95)$, and the difference $=$ $0.93 \mathrm{~min}, \mathrm{~F}=14.210, \mathrm{P}=0.000<0.01$; in-motion effects, the experimental group $(8.31$ $\pm .91)$, the control group $(6.96 \pm 0.90)$, and the difference $=1.35 \mathrm{~min}, \mathrm{~F}=31.428, \mathrm{P}=$ $0.000<0.01$. Order of ranking in descending order: motion effects, action convergence, the number of combinations action, action novel. This is because aerobics exercise self movement of technical movements, the overall effects of the action is very important, is the key to attract attention, it needs to join the action as a link, a combination of the number of actions to ensure that, while there is a certain degree of innovation and new and resulting in. Visible, motion effects, action convergence, the number of combinations action, action novel were very significant increase.

Table 8. Evaluation of the Students' Exercise Action Technique $(n=57)$

\begin{tabular}{|c|c|c|c|c|c|}
\hline Index & $\begin{array}{c}\text { Experimental } \\
\text { group }(\mathrm{X} \pm \mathrm{S})\end{array}$ & $\begin{array}{c}\text { Control } \\
\text { group }(\mathrm{X} \pm \mathrm{S})\end{array}$ & difference & $\begin{array}{c}\mathrm{F} \\
\text { value }\end{array}$ & $\begin{array}{c}\mathrm{P} \\
\text { value }\end{array}$ \\
\hline Novelty of action & $8.64 \pm 0.94$ & $7.83 \pm 1.09$ & 0.81 & 8.695 & 0.005 \\
\hline Action connection & $8.62 \pm 0.64$ & $7.55 \pm 1.06$ & 1.07 & 20.995 & 0.000 \\
\hline Action combination & $8.07 \pm 0.90$ & $7.14 \pm 0.95$ & 0.93 & 14.210 & 0.000 \\
\hline Action effect & $8.31 \pm .91$ & $6.96 \pm 0.90$ & 1.35 & 31.428 & 0.000 \\
\hline
\end{tabular}

4.2.4. Mental Health after the Experiment: After the experiment the experimental group and the control group to measure mental health, through SPSS software processing, the results in Table 9 show: in normal intelligence, the experimental group $(8.21 \pm 1.11)$, in the control group $(7.57 \pm 1.26)$, and the difference $=$ points, $\mathrm{F}=4.076, \mathrm{P}=0.048<0.05$; at the appropriate emotional control, the experimental group $(7.52 \pm 1.74)$, in the control group $(6.36 \pm 1.97)$, and the difference $=\min , \mathrm{F}=5.559, \mathrm{P}=0.022<0.05$; against he can 
make a proper evaluation of the experimental group $(7.86 \pm 1.85)$, in the control group $(6.79 \pm 1.91)$, and the difference $=\min , \mathrm{F}=4.675, \mathrm{P}=0.035<0.05$; in maintaining good relationships, experiments group (7.58 \pm 1.63$)$, in the control group $(6.28 \pm 1.60)$, and the difference $=\min , \mathrm{F}=9.155, \mathrm{P}=0.004<0.01$. In descending order of ranking were: to maintain good relationships, appropriate emotional control ability, he can make a proper evaluation, normal intelligence. This is because teaching aerobics movement, the need to cooperate with each other, interpersonal cooperation in more reasonable, but also to control their negative emotions, for their confidence, a proper understanding of and assess themselves, constantly receiving new things and intelligence and improve and lead. Visible, to maintain good relationships have a very significant increase, appropriate emotional control ability, we can make a proper evaluation, normal intelligence were significantly improved.

Table 9. Mental Health Indicators after Experiment $(n=57)$

\begin{tabular}{|c|c|c|c|c|c|}
\hline Index & $\begin{array}{c}\text { Experimental group } \\
(\mathrm{X} \pm \mathrm{S})\end{array}$ & $\begin{array}{c}\text { Control group } \\
(\mathrm{X} \pm \mathrm{S})\end{array}$ & difference & $\begin{array}{c}\mathrm{F} \\
\text { value }\end{array}$ & $\begin{array}{c}\mathrm{P} \\
\text { value }\end{array}$ \\
\hline $\begin{array}{c}\text { Normal } \\
\text { intelligence }\end{array}$ & $8.21 \pm 1.11$ & $7.57 \pm 1.26$ & 0.81 & 4.076 & 0.048 \\
\hline Emotional control & $7.52 \pm 1.74$ & $6.36 \pm 1.97$ & 1.07 & 5.559 & 0.022 \\
\hline $\begin{array}{c}\text { Appropriate } \\
\text { evaluation }\end{array}$ & $7.86 \pm 1.85$ & $6.79 \pm 1.91$ & 0.93 & 4.675 & 0.035 \\
\hline $\begin{array}{c}\text { Good interpersonal } \\
\text { skills }\end{array}$ & $7.58 \pm 1.63$ & $6.28 \pm 1.60$ & 1.35 & 9.155 & 0.004 \\
\hline
\end{tabular}

\section{Conclusion}

Through the above results and analysis, it can be seen that with the development of the information age, education to the world and the modernization, modernization must go, and the advantages of information in the form of diversification is the multimedia technology and network technology, multimedia applied Teaching has become a necessity of the times, the gradual deepening of multimedia assisted teaching classroom, its superior performance has become increasingly significant, has become an important means of teaching process; become a standard evaluation of teacher education modernization, the application of multimedia assisted teaching has undoubtedly become modern a trend in education. The results showed that female students harmonious teaching in aerobics teaching, can be very significant improvement Sit and Reach, significantly improved heart rate, weight, sit-ups, 800 meters, 50 meters, long jump, standing unchanged. Harmonious teaching female students in technical action aerobics exercise, motion effects, action convergence, and the number of combinations action, action novelty, accuracy and movement dynamics action were very significant increase. Range of motion and action expressive significantly improved. Harmonious teaching can be very significant increase to maintain good relationships, a significant increase appropriate e motional control ability, we can make a proper evaluation, normal intelligence, promote mental health and personality perfectly. 


\section{Acknowledgment}

This work is financially supported by Social science "Twelfth Five Year Plan" project in Ji'an City, Jiangxi province (No. 15gh099).

\section{References}

[1] S. Ji. Hua and L. Hong, "Explore the Effective Use of Multimedia Technology in College Physics Teaching", Energy Procedia, (2012).

[2] A. K. Kim and J. Davies, "A teacher's perspective on student centred learning: Towards the development of best practice in an undergraduate tourism course", Journal of Hospitality, Leisure, Sport \& Tourism Education, vol. 25, (2014), pp. 6-14.

[3] M. Hu and S. Xu, "Research of Multimedia Teaching on Principles of Management", IERI Procedia, (2012).

[4] C. Krstev and A. Trtovac, "Teaching Multimedia Documents to LIS Students", The Journal of Academic Librarianship, vol. 40, no. 2, (2014), pp. 152-162.

[5] C. Wei and Y. Tao, "Application of Multimedia-Aided Project-Teaching Mode in Cultural Education", IERI Procedia, (2012).

[6] H. Janta and P. Lugosi, "Migrant networks, language learning and tourism employment", Tourism Management, vol. 33, no. 2, (2012), pp. 431-439.

[7] W. Dai and L. Fan, "Discussion about the Pros and Cons and Recommendations for Multimedia Teaching in Local Vocational Schools", Physics Procedia, (2012).

[8] M. Sigala, "Investigating the role and impact of geovisualisation and geocollaborative portals on collaborative e-learning in tourism education", Journal of Hospitality, Leisure, Sport \& Tourism Education, vol. 11, (2012), pp. 50-66.

[9] Y. Huang and S. Backman, "Experiencing student learning and tourism training in a 3D virtual world: An exploratory study", Journal of Hospitality, Leisure, Sport \& Tourism Education, vol. 13, (2013), pp. 190-201.

[10] C. Zhang and X. Chen, "Use of Multimedia in Gross Infective Pathogen Experimental Teaching", Procedia Engineering, (2012). 
International Journal of $u-$ and e- Service, Science and Technology Vol.8, No. 12 (2015) 